\title{
COMPREHENSIVE ANALYSIS OF FLYING ALTITUDE FOR HIGH RESOLUTION SLOPE MAPPING USING UAV TECHNOLOGY
}

\author{
A. R. Yusoff ${ }^{1}$, N. Darwin², Z. Majid², M. F. M. Ariff², K. M. Idris², \\ ${ }^{1}$ Dept. of Geoinformation, Faculty of Geoinformation and Real Estate, Universiti Teknologi Malaysia, Skudai, Johor, Malaysia - \\ ahmadrazali89@gmail.com \\ ${ }^{2}$ Geospatial Imaging and Information Research Group, Faculty of Geoinformation and Real Estate, Universiti Teknologi Malaysia, \\ Skudai, Johor, Malaysia - (norhadija2, zulkeplimajid, mfaridma, khairulnizami)@utm.my
}

Commission VI, WG VI/4

KEY WORDS: Flying Altitudes, Ground Control Point (GCP), High Resolution Imagery, 3D Slope Mapping, UAV

\begin{abstract}
:
Unmanned Aerial Vehicle (UAV) is one of the geoinformation data acquisition technologies that popularly used for slope mapping. UAV is capable to produce high resolution imageries in a short period. In order to obtained suitable results in slope mapping, specific UAV mapping factors have to be followed and the selection of the optimum Ground Control Point (GCP) and the UAV flying altitude become the most important factors. This paper presents the production of high resolution slope map using UAV technology. The research involved with the following steps, (i) preparation of field work (i.e. determination of the number of GCPs and flying altitude) and the flight mission; (ii) processing and evaluating of UAV images, and (iii) production of slope map. The research was successfully conducted at Kulim, Kedah, Malaysia as the condition of slope in that area is prone to the landslide incidences. A micro rotary wing UAV system known as DJI Phantom 4 was used for collecting the high resolution images with various flying altitudes. Due to the un-accessibility of the slope area, all the GCPs are measured from the point cloud data that was acquired from the Pheonix AL-32 LiDAR system. The analysis shows that the coordinates (X, Y and Z) accuracy is influenced by the flying altitude. As the flying altitude increases, the coordinate's accuracy also increased. Furthermore, the results also show that the coverage slope area and number of tie point increases when the flying altitude increases. This practical study contributed to the slope work activities where the specific requirements for flying altitudes have been clearly stated.
\end{abstract}

\section{INTRODUCTION}

\subsection{Background}

A slope area is associated with the height of an area as it becomes higher thus the steeper is the gradient. The risk of landslides may occur when the height of the slopes increases and becomes unstable (Knapen et al., 2006). Landslide is one of the disasters related with land unstable condition that can lead to damage of property and death. Landslide is a geological incident which includes most of the earth's movements, such as falling rocks (Hungr et al., 1999; Trappmann et al., 2014), and slope failures (Arnold et al., 2015; Hori and Tamate, 2018). There are several factors that causes landslides such as: (a) gravity acts on the slope (Reis et al., 2016) ; (b) erosion by rivers, glaciers, or sea waves which produce steep slopes (Blyth and de Freitas, 2017); (c) sloping rock or land slopes due to saturation by heavy rain; (d) an earthquake that produces tensions causing weak slopes to collapse; (e) volcanic eruptions produce ash, heavy rain, and trash flow; (f) tremors from machines, traffic, explosives, even thunder may trigger tremendous collapse; (g) extreme weight resulting from the accumulation of rain or snow, stacks of rocks or ores, from garbage dumps, or man-made structures that put pressure on weak to heavy cracks and other structures; (h) Groundwater pressure acts to make the slope unstable on shallow soils, deeprooted plantings that bind colluvium to base stones.

These factors can affect a slope condition in a long-term if not monitored regularly. The main thing that needs to be done is monitoring the slope area that prone to landslide incidence. Slope mapping is one of the approaches to monitor the slope area where the generated maps can be combined with geology inputs and environmental engineering of an area. The slope map is intended to be frequently produced for landslide mapping as a reference material to stakeholders such as developers, researchers and local authorities. There are several technologies that have been used in monitoring and mapping of slope area such as satellite imagery (Bagnardi et al., 2016), Light Ranging and Radar (LiDAR) (Dunham et al., 2017), Terrestrial Laser Scanner (TLS) (Francioni et al., 2014; Tahar, 2015), manned aircraft, Total Station, Mobile Laser Scanner (MLS) (Michoud et al., 2015), Global Positioning System (GPS) and Unmanned Aerial Vehicle (UAV). Table 1 shows the summary of the comparison between these technologies.

All these technologies are used to produce the slope map which has its own capabilities and limitations. For an example, satellite imagery have potential for covering large area with different image resolution, however, most of the images in tropical region are covered with cloud (Al-Tahir et al., 2011). For LiDAR technology and manned aircraft, both requires huge budget reaching up to hundred thousand Ringgit Malaysia but provide accurate map. Meanwhile, total station required a lot of time and manpower from fieldwork until map production (Tahar, 2015). Furthermore, this technique only measure bearing and distance on the earth's surface which impractical for performing fast and cost saving projects. Moreover, laser scanning either mobile or terrestrial are techniques used for obtaining 3D coordinate data and it capable to scan highdensity data of an object or surfaces. GPS is used for obtaining 3D coordinates with accurate result but limited in mapping application. Presently, UAV is often used and become more popular in monitoring and mapping application since it can provide map data in a short period. 


\begin{tabular}{|c|c|c|c|c|c|c|}
\hline Technology & Flight Planning & $\begin{array}{l}\text { Flight } \\
\text { Restriction }\end{array}$ & $\begin{array}{l}\text { Cost } \\
\text { Estimation }\end{array}$ & $\begin{array}{l}\text { Production } \\
\text { Rate }\end{array}$ & $\begin{array}{l}\text { Coverage } \\
\text { Area }\end{array}$ & Accuracy \\
\hline $\begin{array}{l}\text { Satellite } \\
\text { Imagery }\end{array}$ & - & $\begin{array}{l}\text { Most image in } \\
\text { the tropical } \\
\text { region cover } \\
\text { with cloud }\end{array}$ & $\begin{array}{l}\text { Up to ten } \\
\text { thousand (there } \\
\text { is also free of } \\
\text { charge satellite } \\
\text { imagery, i.e. } \\
\text { Landsat) }\end{array}$ & $\begin{array}{l}\text { Depend on } \\
\text { satellite } \\
\text { which passes } \\
\text { through the } \\
\text { area }\end{array}$ & $\begin{array}{l}\text { Cover large } \\
\text { area }\end{array}$ & Up to $\mathrm{m}$ \\
\hline LiDAR & $\begin{array}{l}\text { More complex } \\
\text { due to small } \\
\text { strips and } \\
\text { potential data } \\
\text { voids }\end{array}$ & $\begin{array}{l}\text { Less impact } \\
\text { from weather, } \\
\text { day/night, cloud } \\
\text { condition }\end{array}$ & $\begin{array}{l}\text { Up to hundred } \\
\text { thousand ringgit } \\
\text { Malaysia }\end{array}$ & $\begin{array}{l}\text { Can be } \\
\text { automated and } \\
\text { faster }\end{array}$ & $\begin{array}{l}\text { Cover large } \\
\text { area } \\
\text { and not } \\
\text { practical to } \\
\text { cover small } \\
\text { area }\end{array}$ & $\begin{array}{l}\text { Up to } \mathrm{cm} \\
\text { and can be } \\
\mathrm{mm} \\
\text { accuracy }\end{array}$ \\
\hline TLS & No & No & $\begin{array}{l}\text { Up to hundred } \\
\text { thousand }\end{array}$ & $\begin{array}{l}\text { Can be } \\
\text { automated and } \\
\text { faster }\end{array}$ & $\begin{array}{l}\text { Limited } \\
\text { coverage }\end{array}$ & Up to $\mathrm{cm}$ \\
\hline $\begin{array}{l}\text { Manned } \\
\text { Aircraft }\end{array}$ & $\begin{array}{l}\text { Overlap and } \\
\text { side lap need to } \\
\text { be considered }\end{array}$ & $\begin{array}{l}\text { Must fly during } \\
\text { day time and } \\
\text { need clear sky }\end{array}$ & $\begin{array}{l}\text { Up to hundred } \\
\text { thousand ringgit } \\
\text { Malaysia }\end{array}$ & $\begin{array}{l}\text { Time } \\
\text { consuming }\end{array}$ & $\begin{array}{l}\text { Cover large } \\
\text { area } \\
\text { and not } \\
\text { practical to } \\
\text { cover small } \\
\text { area }\end{array}$ & Up to $\mathrm{cm}$ \\
\hline Total Station & No & No & $\begin{array}{l}\text { Up to } \\
\text { thousand } \\
\text { ringgit } \\
\text { Malaysia }\end{array}$ & $\begin{array}{l}\text { Time } \\
\text { consuming }\end{array}$ & $\begin{array}{l}\text { Limited } \\
\text { coverage }\end{array}$ & Up to $\mathrm{mm}$ \\
\hline MLS & No & No & $\begin{array}{l}\text { Up to houndred } \\
\text { thousand }\end{array}$ & $\begin{array}{l}\text { Can be } \\
\text { automated and } \\
\text { faster }\end{array}$ & & Up to $\mathrm{cm}$ \\
\hline GPS & No & No & $\begin{array}{l}\text { Up to } \\
\text { thousand } \\
\text { ringgit } \\
\text { Malaysia }\end{array}$ & $\begin{array}{l}\text { Can be } \\
\text { automated and } \\
\text { faster }\end{array}$ & $\begin{array}{l}\text { Limited } \\
\text { coverage }\end{array}$ & Up to $\mathrm{mm}$ \\
\hline UAV & $\begin{array}{l}\text { Overlap and } \\
\text { side lap need to } \\
\text { be considered }\end{array}$ & $\begin{array}{l}\text { Must fly } \\
\text { during day, } \\
\text { clear sky time } \\
\text { and under } \\
\text { cloud }\end{array}$ & $\begin{array}{l}\text { Up to } \\
\text { thousand } \\
\text { ringgit } \\
\text { Malaysia }\end{array}$ & $\begin{array}{l}\text { Can be } \\
\text { automated } \\
\text { and rapid }\end{array}$ & $\begin{array}{l}\text { cover small } \\
\text { area based on } \\
\text { micro UAV } \\
\text { and cover } \\
\text { large area } \\
\text { based on long } \\
\text { endurance } \\
\text { UAV }\end{array}$ & Up to $\mathrm{cm}$ \\
\hline
\end{tabular}

Table 1 . The summary of the comparison between these technologies.

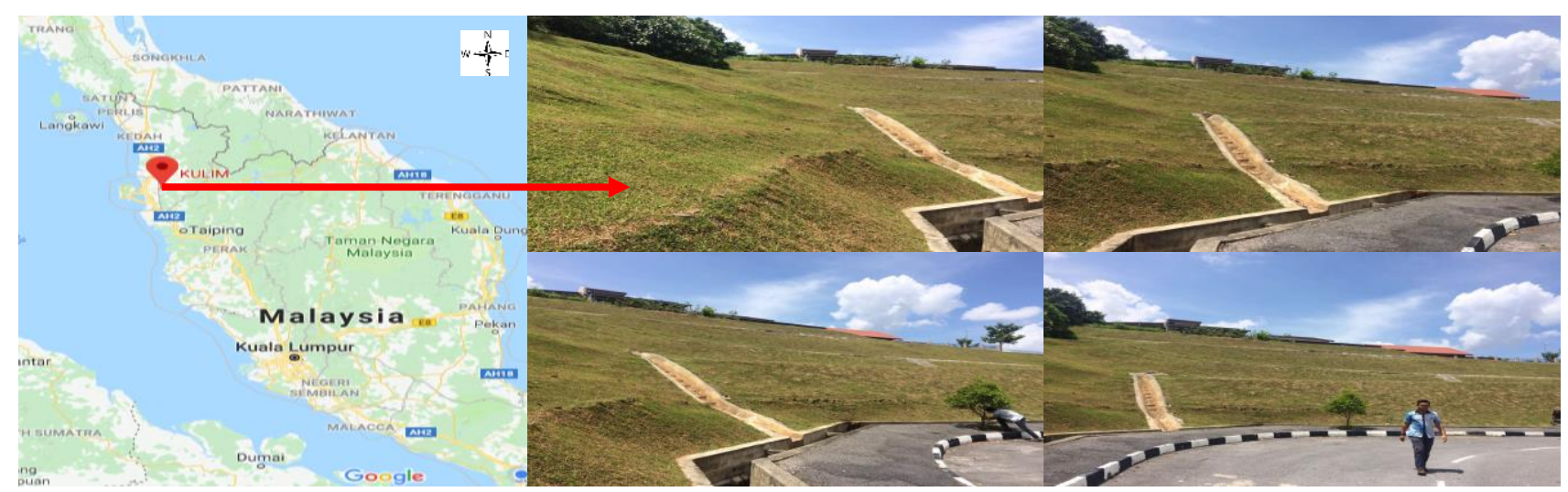

Figure 1. Study area 
Initially, the UAV has been introduced for military and surveillance purposes. With the advancement of technology and instrumentation surveying, the importance of using UAV has been seen by researchers, surveyors and practioners. By using photogrammetry concept, mapping application can provide up to sub-centimetre accuracy. Photogrammetry concept has been introduced since 1990 which divided into close range, aerial and terrestrial photogrammetry. UAV photogrammetry was introduced by Henri Eisenbess in year 2009 through his study for capturing images of cultural heritage using close range photogrammetry concept. UAV is one of the geoinformation data acquisition technologies which can be used to monitor the slope of the area experiencing instability. It is believed that this technology can be used in producing high resolution images and also can speed up the process of getting information of the incident.

In producing slope mapping, the most important part is getting the accurate result for detecting the changes of the slope area. According to Tahar (2013), number of ground control points and flying altitudes are the most important aspect need to be consider during data acquisitions. These two aspects can influence the accuracy of the produced map. Therefore, this paper presents the production of high resolution slope map using UAV technology. The research involved with the following steps, (i) preparation of field work (i.e. determination of the flying altitude) and the flight mission; (ii) processing and evaluating of UAV images, and (iii) production of slope map.

\subsection{Applications of UAV}

UAV technology become popular all over the world due to its rapid development and people awareness on the importance of UAV usage especially among surveyors, researchers, government agencies and others. An aerial image is an output obtained from UAV technology which used in the field of mapping and remote sensing. Digital camera or any sensors mounted to UAV used for capturing object on the earth's surface accordance to the flight path. Digital camera can be mounted either in horizontal or vertical based on the purposes of study. There were several studies have been conducted in mapping and monitoring using UAV such as cultural heritage (Eisenbeiss et al., 2005), agricultural (Eves et al., 2014), urban planning (Spatalas et al., 2006), 3D modelling (Remondino et al., 2011), coastal (Darwin et al., 2014; Gonçalves and Henriques, 2015), landslide (Everaerts, 2008), river mapping(Ahmad et al., 2013; Alho et al., 2009) and others. The advantage of UAV is able to carry different types of sensors and items for various applications. In addition, the use of UAV reduces human risk, cost and manpower which are suitable for project that involve with risky or disaster areas. UAV also widely used in the agricultural sector to evaluate the soil conditions, identifying pests that attack soil, soil mapping or spreading seeds, pesticides and water (Krishna, 2016). All UAV applications either in mapping or non-mapping fields requires different method, accuracy and standard of procedure.

\subsection{Significant of Study}

Some applications do not concern with the accuracy and only require the overview of the area. Moreover, most of the projects are handled by small company which usually involves small areas where the use of UAV technology is practical. High resolution aerial images also can be obtained using UAV technology where it can fly with low flying altitude and under cloud cover.

\subsection{Study Area}

The study area is situated in Kulim, Kedah, Malaysia (Figure 1) where three different flying altitudes and numbers of GCPs were performed. The main factor for this research was conducted at Kulim, Kedah, Malaysia due to the condition of slope in that area is prone to the landslide incidences. The slope mapping produced in this study based on the data collection conducted in November 2017.

\section{INSTRUMENTS}

\subsection{DJI Phantom 4}

Rotary wing UAV known as DJI Phantom 4 was used in this study. DJI Phantom 4 was equipped with gimbal, vision system, camera, remote controller, charger, live view and intelligent flight battery. This DJI Phantom 4 has an advanced stereo Vision Positioning System (VPS) which make it able to fly precisely, easier and safer without satellite positioning. Figure 2 show DJI Phantom 4 with remote controller and Table 2 shows details specification of DJI Phantom 4.

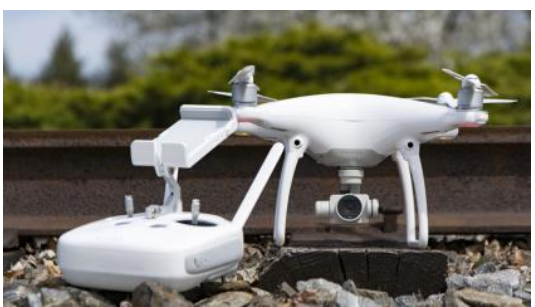

Figure 2. DJI Phantom 4

\begin{tabular}{|l|c|}
\hline \multicolumn{2}{|c|}{ Specification } \\
\hline Weight & $1380 \mathrm{~g}$ \\
Diagonal Size & $350 \mathrm{~mm}$ \\
Max Ascent Speed & S-mode: $6 \mathrm{~m} / \mathrm{s}$ \\
Max Descent Speed & S-mode: $4 \mathrm{~m} / \mathrm{s}$ \\
Max Speed & S-mode: $20 \mathrm{~m} / \mathrm{s}$ \\
Max Tilt Angle & S-mode: $42^{\circ}$ \\
& A-mode: $35^{\circ}$ \\
Max Angular Speed & P-mode: $15^{\circ}$ \\
& S-mode: $200^{\circ} / \mathrm{s}$ \\
Max Service Ceiling Above Sea & A-mode: $150^{\circ} / \mathrm{s}$ \\
Level & 19685 feet $(6000 \mathrm{~m})$ \\
Max Wind Speed Resistance & $10 \mathrm{~m} / \mathrm{s}$ \\
Max Flight Time & Approx. $28 \mathrm{minutes}$ \\
Operating Temperature Range & $32^{\circ}$ to $104^{\circ} \mathrm{F}\left(0^{\circ}\right.$ to \\
Satellite Positioning Systems & $\left.40^{\circ} \mathrm{C}\right)$ \\
Hover Accuracy Range & GPS/GLONASS \\
& Vertical: \\
& \pm 0.1 m (with Vision \\
& Positioning) \\
& \pm 0.5 m (with GPS \\
& Positioning) \\
Horizontal: \\
\end{tabular}

Table 2. DJI Phantom 4 Specification 


\subsection{Camera}

In this study, digital camera was used which has been attached at the DJI Phantom 4 has 12.4 megapixel and other specification as shown in Table 2. It has four (4) blades in which two blades rotate in clockwise direction and another two blades rotate in counter-clockwise direction. The DJI Phantom 4 is more stable and safe to be used for outdoor and indoor activities, especially in the urban area and it is capable to capture images from certain altitude.

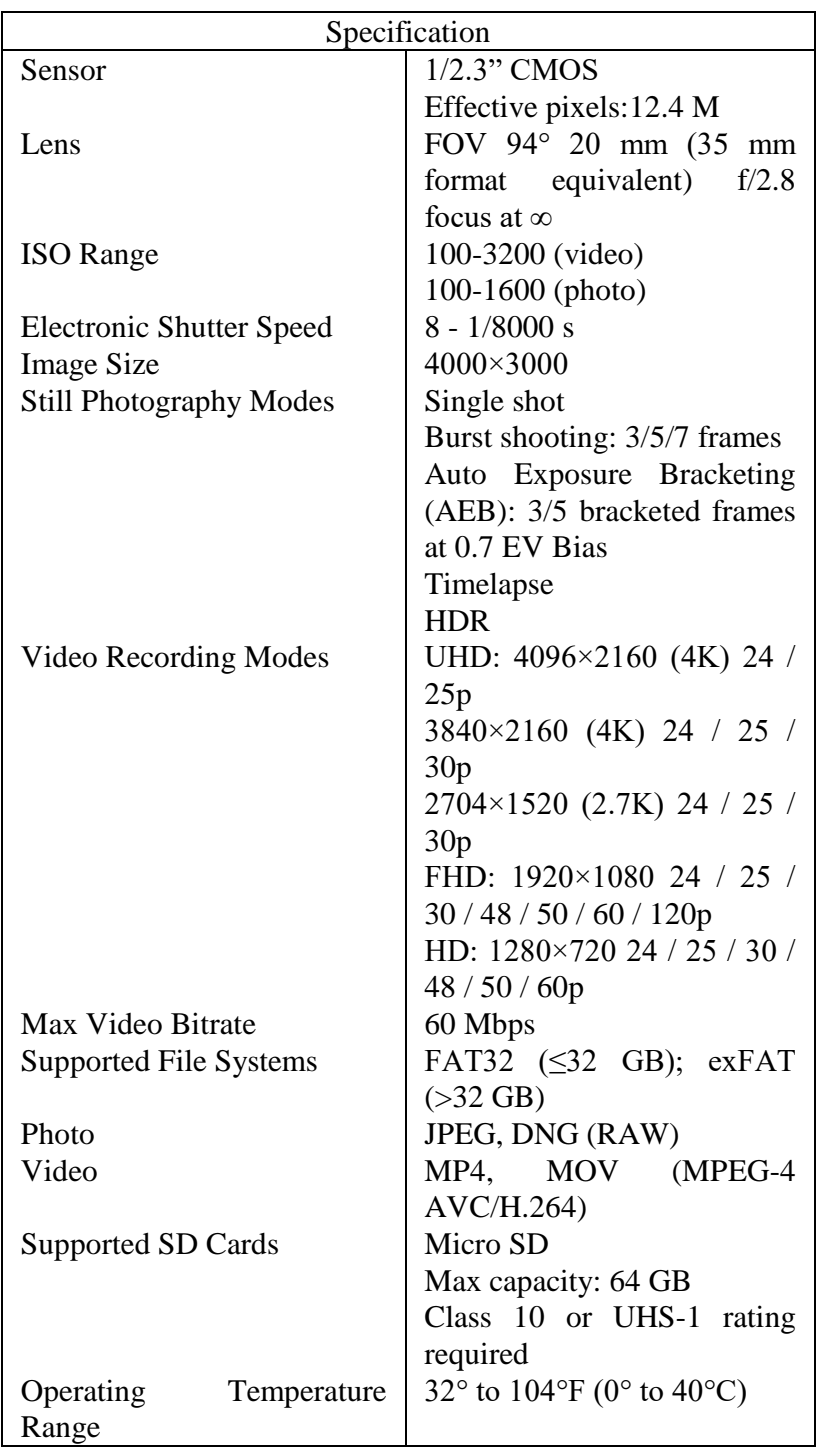

Table 3. Camera Specification

\subsection{Global Positioning System (GPS)}

In this study, static observation of GPS was used for ground control points (GCPs) establishment. This observation technique only takes around 20 to 30 minutes per point. In addition, this technique can provide millimetres accuracy for absolute orientation or exterior orientation and to perform aerial triangulation. This GPS instruments is the combination of a compact form factor, revolutionary Universal tracking technology, and multiple communication methods. The Topcon GR-5 receiver is the most popular and versatile option for high precision GNSS reliability where it capable to tracking GPS, GLONASS, BeiDou, Galileo, QZSS constellations. Figure 3 shows the static GPS observation using Topcon GR-5.

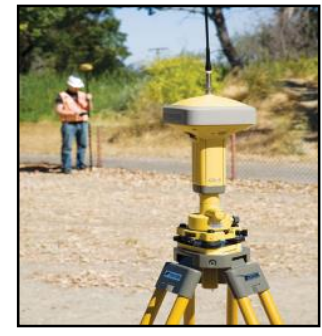

Figure 3. CPs Establishment through GPS observation

\section{RESEARCH METHODOLODY}

In this study, the research methodology involves three main phases, namely data acquisition, data processing and data analysis. The DJI Phantom 4 was flying at three different flying altitudes such as $30 \mathrm{~m}, 40 \mathrm{~m}$ and $50 \mathrm{~m}$.

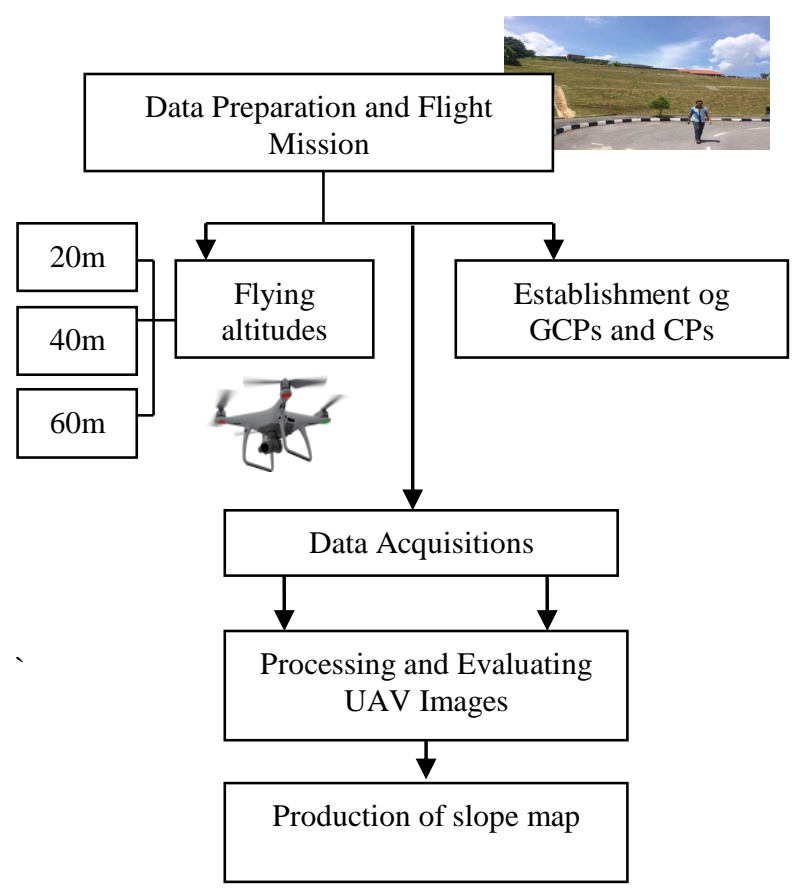

Figure 4. Research methodology

Minimum of five (5) GCPs numbers is required for the image processing software. The details explanations of fieldwork preparation, processing and evaluating UAV images and production of Slope Map discussed in the next sub sections.

\subsection{Preparation of Field Work and the Flight Mission}

Image acquisition is an important step that needs to be completed in order to get the best aerial images. The flight planning needs to be settled beforehand capturing the aerial images. Several considerations need to be clarified during flight planning such as flying altitude, coverage of the study area, focal length, scale, percentage of the end and side lap. In real site image acquisition, the important part depends on weather and time taken of aerial images of the study area which could affect the brightness of images. For the two real sites of study area, the best time to acquire aerial images is about from 8.00 am until $11.30 \mathrm{am}$ in the morning. 
Two people were put in-charge during the flight mission namely the pilot and the ground crew. In this study, autonomous micro rotary wing UAV for image acquisition was implemented for flight mission and landing. In the autonomous mode, micro rotary wing UAV received input from laptop or mission planner via radio modem and was flown based on the starting waypoints until the end of waypoints. However, an operator must be alert at all time to avoid accident during the flight mission (Tahar, 2013).

\subsection{Processing and Evaluating of UAV Images}

Data processing was carried out after the required data were acquired successfully. In this study, the data processing was involved the following; (a) The collected data were processed by using ArcGIS software was employed to produce map either in softcopy or/and hardcopy; (b) The GCPs and CPs obtained from ground survey measurement (i.e. total station and GPS rapid static technique) were processed by using to obtain the $3 \mathrm{D}$ coordinates of these points. Figure 5 shows the distribution of GCPs and CPs of the slope area.

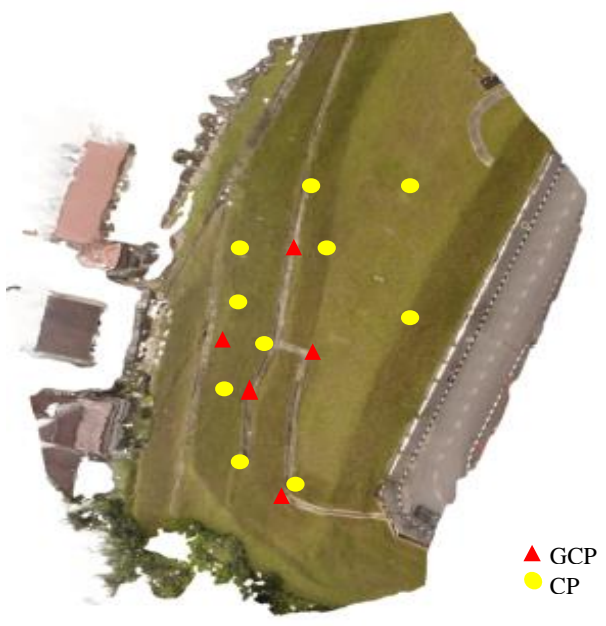

Figure 5. Distribution of GCPs and CPs of the slope area

\subsection{Production of Slope Mapping}

This stage was conducted after performing the processing and evaluating of UAV images. There are two slope mapping produced in this study namely, orthophoto and DEM mapping of slope area. Figure 6, 7 and 8 shows the orthophoto produced based on three different flying altitudes. Meanwhile, Figure 9, 10 and 11 shows the DEM produced based on three different flying altitudes.

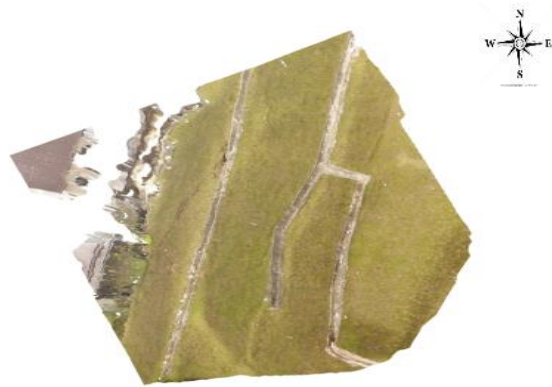

Figure 6. Orthophoto for flying altitude of $20 \mathrm{~m}$

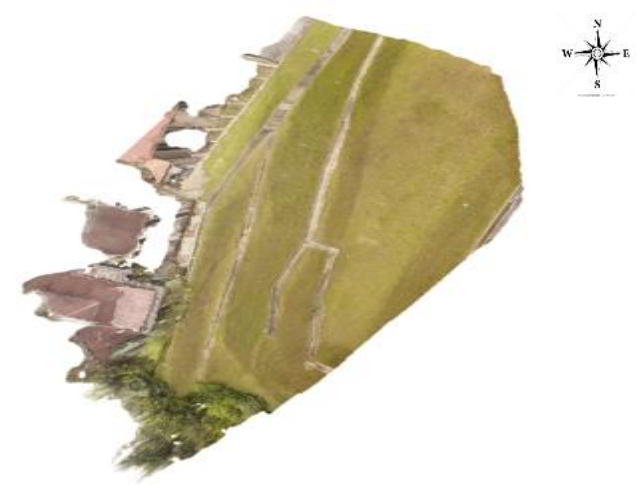

Figure 7. Orthophoto for flying altitude of $40 \mathrm{~m}$

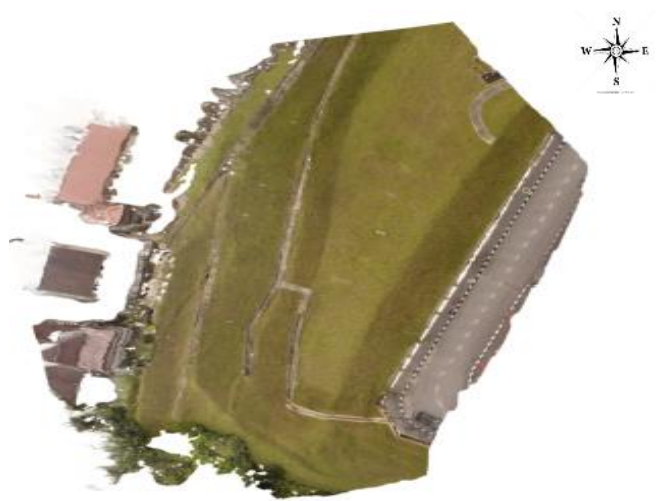

Figure 8. Orthophoto for flying altitude of $60 \mathrm{~m}$

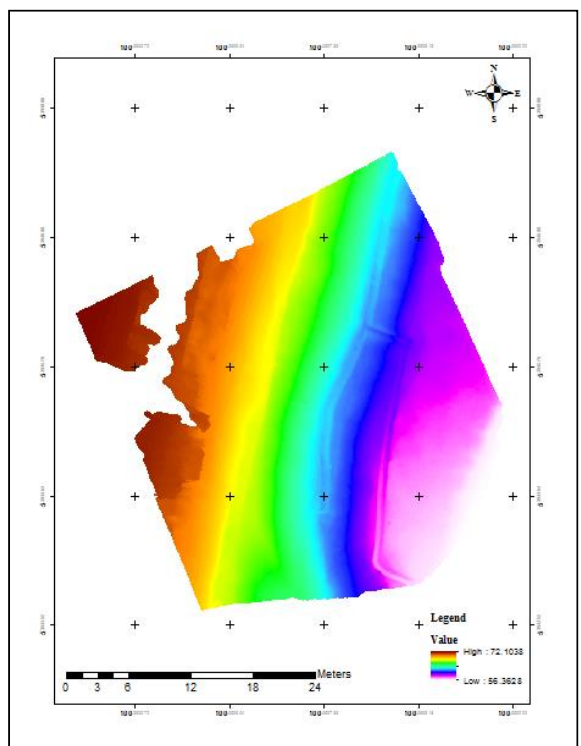

Figure 9. DEM for flying altitude of $20 \mathrm{~m}$ 


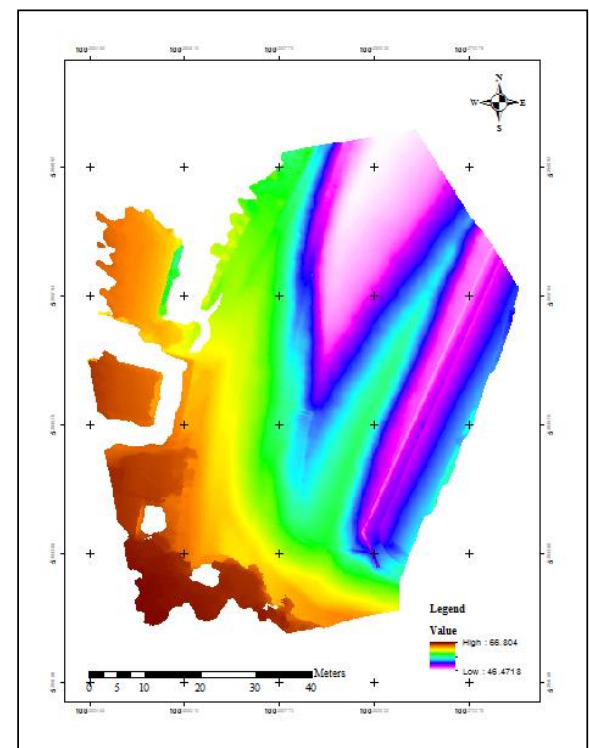

Figure 10. DEM for flying altitude of 40m

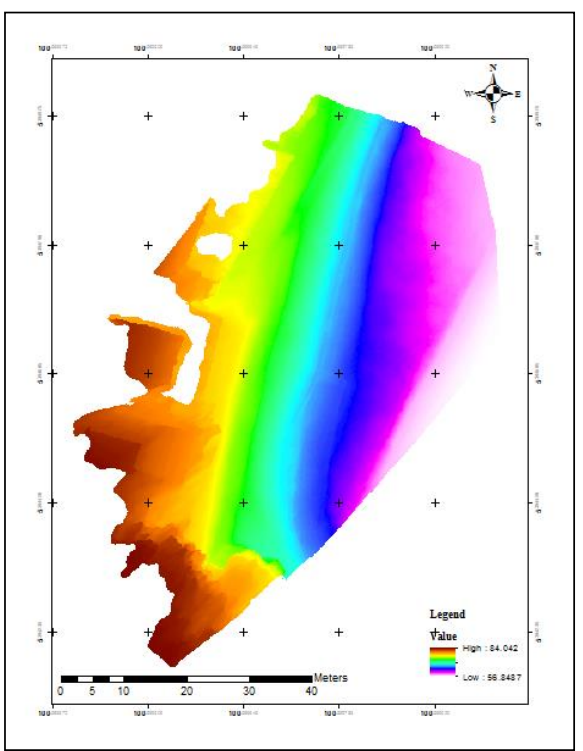

Figure 11. DEM for flying altitude of $60 \mathrm{~m}$

\section{RESULT AND ANALYSIS}

There are two main results produced in this study, namely orthophoto and digital elevation model (DTM). Both of results contains horizontal and height coordinates which can be used to give information of movement points of the slope area. Orthophoto and DEM results contain $\mathrm{X}, \mathrm{Y}$ and $\mathrm{Z}$ coordinates. Figure 6, 7 and 8 illustrates the orthophoto of the slope area produced after through image processing step. Orthophoto specifically contain horizontal coordinate which gives provides clear images with high resolution and up-to-date information; in other words, data on demand can be produced by using the micro UAV. Meanwhile, Figure 9, 10 and 11 shows the DEM of the slope area which gives height information where the brown and magenta colour represents the highest and lowest value for three different flying altitudes respectively. The DEM shows the different highest and lowest value. The lowest value

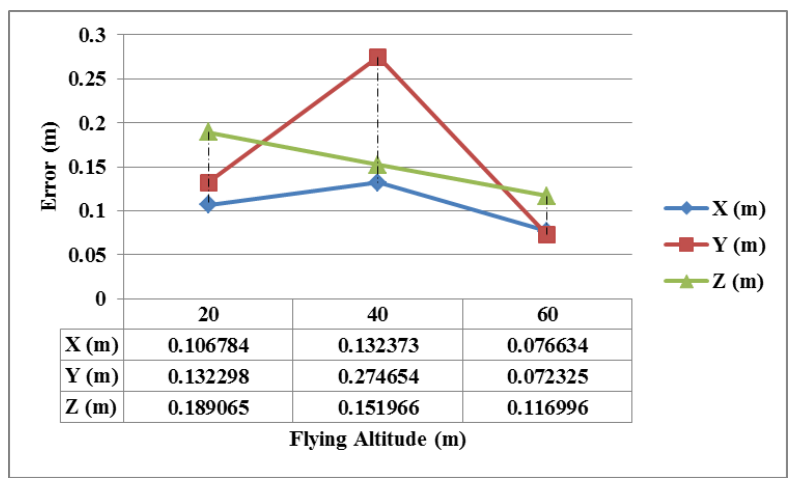

Figure 12. Error at different flying altitudes

of the slope area are $56.849 \mathrm{~m}, 56.363 \mathrm{~m}$ and $46.472 \mathrm{~m}$ at $20 \mathrm{~m}$, $40 \mathrm{~m}$ and $60 \mathrm{~m}$ flying altitudes, respectively. Whereas, the highest value of the slope area are $84.042 \mathrm{~m}, 72.104 \mathrm{~m}$ and $68.804 \mathrm{~m}$ at $20 \mathrm{~m}, 40 \mathrm{~m}$ and $60 \mathrm{~m}$ flying altitudes, respectively. Based on Figure 12, it was found that the flying altitudes influenced the error of the aerial images. The error of the map is decreased when the flying altitudes is increased. It represents all the error of $\mathrm{X}, \mathrm{Y}$ and $\mathrm{Z}$ below one (1) meter. Figure 13 shows the relationships between number of tie points, coverage area and flying altitudes. The coverage area and number of tie point increases when the flying altitude increases.

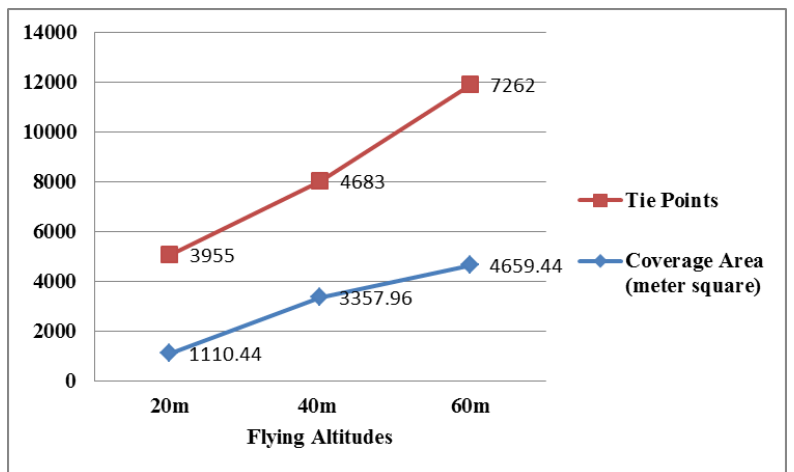

Figure 13. Number of tie points and coverage area at three different altitudes

\section{CONCLUSION}

As conclusion, this study has successfully evaluates the orthophoto and DEM accuracy based on different flying altitudes using UAV technology to produced slope map. It also demonstrates the capability of UAV technology to fly at three different altitudes over the study area. Three different flying altitudes were performed, namely $20 \mathrm{~m}, 40$, and $60 \mathrm{~m}$. Throughout the study investigation, the overall error of $\mathrm{X}, \mathrm{Y}$ and $\mathrm{Z}$ value at different altitudes for the study area are at centimeter level. Different flying altitudes have influence on the error of $\mathrm{X}, \mathrm{Y}$ and $\mathrm{Z}$ which means the higher the altitudes, the smaller will be the error of coordinates obtained. In addition, the analysis showed that the coverage of slope area and number of tie point increases when the flying altitude increases. Subsequently, this practical study contributed to the slope work activities where the specific requirements for flying altitudes have been clearly stated. It is recommended in future studies, this study will expand analysis using unmanned aerial vehicle (UAV) attached with multi sensor such as LiDAR, thermal camera, and infrared to capture slope data. 


\section{ACKNOWLEDGEMENTS}

The authors would like to express their sincere appreciation to Universiti Teknologi Malaysia (UTM) under GUP Tier 2 (Vot. 14J96) is for supporting this study.

\section{REFERENCES}

Ahmad, A., Tahar, K. N., Udin, W. S., Hashim, K. A., Darwin, N., Hafis, M., Azmi, S. M. (2013). Digital aerial imagery of unmanned aerial vehicle for various applications. Paper presented at the Control System, Computing and Engineering (ICCSCE), 2013 IEEE International Conference on.

Al-Tahir, R., Arthur, M., and Davis, D. (2011). Low Cost Aerial Mapping Alternatives for Natural Disasters in the Caribbean. Paper presented at the FIG Working Week.

Alho, P., Kukko, A., Hyyppa, H., Kaartinen, H., Hyyppa, J., and Jaakkola, A. (2009). Application of boat-based laser scanning for river survey. Earth Surface Processes and Landforms, 34(13), 1831-1838. doi: 10.1002/esp. 1879

Arnold, L., Wartman, J., Massey, C., MacLaughlin, M., and Keefer, D. (2015). Insights into the seismicallyinduced rock-slope failures in the Canterbury region using the discrete element method. Paper presented at the 6th International Conference on Earthquake Geotechnical Engineering.

Bagnardi, M., González, P. J., and Hooper, A. (2016). High-resolution digital elevation model from tri-stereo Pleiades-1 satellite imagery for lava flow volume estimates at Fogo Volcano. Geophysical Research Letters, 43(12), 6267-6275.

Blyth, F. G. H., and de Freitas, M. (2017). A geology for engineers: CRC Press.

Darwin, N., Ahmad, A., and Zainon, O. (2014). The Potential of Unmanned Aerial Vehicle for Large Scale Mapping of Coastal Area. Paper presented at the IOP Conference Series: Earth and Environmental Science.

Dunham, L., Wartman, J., Olsen, M. J., O'Banion, M., and Cunningham, K. (2017). Rockfall Activity Index (RAI): A lidar-derived, morphology-based method for hazard assessment. Engineering Geology, 221, 184192.

Eisenbeiss, H., Lambers, K., Sauerbier, M., and Zhang, L. (2005). Photogrammetric documentation of an archaeological site (Palpa, Peru) using an autonomous model helicopter. International Archives of Photogrammetry, Remote Sensing and Spatial Information Sciences, 34(5), C34.

Everaerts, J. (2008). The use of unmanned aerial vehicles (UAVs) for remote sensing and mapping. The International Archives of the Photogrammetry, Remote Sensing and Spatial Information Sciences, 37, 1187-1192.

Eves, A., Stewart, T. P., Gay, A. P., Kemp, A., Easey, M., Angel, R., Pearce, D. (2014). Developing unmanned aerial vehicles for local and flexible environmental and agricultural monitoring.

Francioni, M., Salvini, R., Stead, D., and Litrico, S. (2014). A case study integrating remote sensing and distinct element analysis to quarry slope stability assessment in the Monte Altissimo area, Italy. Engineering Geology, 183, 290-302.
Gonçalves, J., and Henriques, R. (2015). UAV photogrammetry for topographic monitoring of coastal areas. ISPRS Journal of Photogrammetry and Remote sensing, 104, 101-111.

Hori, T., and Tamate, S. (2018). Monitoring Shear Strain in Shallow Subsurface Using Mini Pipe Strain Meter for Detecting Potential Threat of Slope Failure. Geotechnical Testing Journal, 41(2).

Hungr, O., Evans, S., and Hazzard, J. (1999). Magnitude and frequency of rock falls and rock slides along the main transportation corridors of southwestern British Columbia. Canadian Geotechnical Journal, 36(2), 224-238.

Knapen, A., Kitutu, M. G., Poesen, J., Breugelmans, W., Deckers, J., and Muwanga, A. (2006). Landslides in a densely populated county at the footslopes of Mount Elgon (Uganda): characteristics and causal factors. Geomorphology, 73(1-2), 149-165.

Krishna, K. R. (2016). Push button agriculture: Robotics, drones, satellite-guided soil and crop management: CRC Press.

Michoud, C., Carrea, D., Costa, S., Derron, M.-H., Jaboyedoff, M., Delacourt, C., Davidson, R. (2015). Landslide detection and monitoring capability of boat-based mobile laser scanning along Dieppe coastal cliffs, Normandy. Landslides, 12(2), 403-418.

Reis, A., Araújo, E., Silva, C., Cruz, A., Gorini, C., Droz, L., Bache, F. (2016). Effects of a regional décollement level for gravity tectonics on late Neogene to recent large-scale slope instabilities in the Foz do Amazonas Basin, Brazil. Marine and Petroleum Geology, 75, 29-52.

Remondino, F., Barazzetti, L., Nex, F., Scaioni, M., and Sarazzi, D. (2011). UAV photogrammetry for mapping and $3 \mathrm{~d}$ modeling-current status and future perspectives. International Archives of the Photogrammetry, Remote Sensing and Spatial Information Sciences, 38(1), C22.

Spatalas, S., Tsioukas, V., and Daniil, M. (2006). The use of remote controlled helicopter for the recording of large scale urban and suburban sites. Culture of Representation, Xanthi, Greece.

Tahar, K. (2013). Photogrammetric Micro Unmanned Aerial Vehicle for Large Scale Slope Mapping. (PhD), University Technology of Malaysia

Tahar, K. N. (2015). Investigation on Different Scanning Resolutions for Slope Mapping Studies in Cameron Highlands, Malaysia. Arabian Journal for Science and Engineering, 40(1), 245-255.

Trappmann, D., Stoffel, M., and Corona, C. (2014). Achieving a more realistic assessment of rockfall hazards by coupling three-dimensional process models and field-based tree-ring data. Earth Surface Processes and Landforms, 39(14), 1866-1875. 